\title{
The Technology Pedagogy Knowledge (TPK) Teacher Using Worksheet 3D Pageflip Professional for Promoting Argumentation Skills' High-Schools Students in Physics Learning
}

\author{
Depi Oktasari ${ }^{1, \mathrm{a})}$, Heru Kuswanto ${ }^{1}$, Ismet $^{2}$, Sardianto M. S. ${ }^{2}$ \\ ${ }^{1}$ Program Pascasarjana, Universitas Negeri Yogyakarta \\ ${ }^{2}$ Fakultas Keguruan dan Ilmu Pendidikan, Universitas Sriwijaya \\ a)depi.oktasari12@gmail.com
}

\begin{abstract}
The demands of 21st-century skills highlighted the importance of cooperation between teachers and students to achieve the expected skill - the Pedagogical knowledge of teachers in teaching and technology into things that need to be developed. The pedagogic ability of teachers in the use of technology can be a potential to improve students' abilities argument. This study aims to develop students' ability argumentation through pedagogical knowledge of teachers in using technology. The technology used is the result of the development of student worksheets 3D PageFlip Impulse and Momentum topics. The purpose of this study to look at the ability of students through the application of scientific argumentation (Technological Pedagogic Knowledge) TPK teachers in the classroom. This research is descriptive research. The data collection capability student argumentation performed by administering a written test. The subjects were students of class X at SMAN 1 Yogyakarta Prambanan. Rate scientific argumentation ability of students refers to Toulmin Argumentation Pattern (TAP). The results showed that the complexity of argumentation ability of students still at low level. These results suggest that the ability of the student arguments need to be improved.
\end{abstract}

Keywords: technology pedagogic knowledge, argumentation skills, 3D Pageflip professional

\section{INTRODUCTION}

The ability of a scientific argument is part of the communication process. Communication skills are an essential part of learning. Communication skills of learners and educators have a considerable influence on the learning process. Communication is the way teachers and students interact in conveying the information (Sadiman \& Haryono 2010). The development of communication skills is essential to achieve the desired learning outcomes (Bell \& Carr 2014). Communication skills are also following the demands of 21st-century skills that must be possessed by learners (Greenstein 2012). In general, communication happens if there is equality the meaning of the message conveyed communicator and well accepted (Mukarom, Rusdiana, \& Rusdiana 2016) Communication skills educators delivering course material must be done so that learners can receive lessons with ease. It is related to the pedagogical abilities of teachers as educators to conduct proper teaching.

Pedagogic good teachers can use teaching techniques using appropriate methods. Effective professional educators must have the skills to communicate and integrate technology in learning (Didi \& Deni 2012). Therefore, the combination of technological knowledge (technology knowledge) 
and pedagogical knowledge (pedagogic knowledge) educators should be raised in any learning process. Educators should be able to take advantage of technological developments to be integrated into classroom teaching activities. Its purpose is as a bridge of communication between teachers and students to achieve the learning objectives. Weak scientific argumentation students will have an impact on communication skills. Communication failure also means failure in the learning process.

The argument is increasingly recognized as a fundamental and important intellectual skill to be learned (Crowell \& Kuhn 2014; Scheuer, Pinkwart, \& McLaren 2010). Arguments become a core part that should be applied in the classroom (Mao, Liu, Roohr, Belur, Mulholland, Lee, \& Pallant 2018). Many international educational curricula that requires students to be able to participate in the argument, debate, and decision-making on science issues (Dawson \& Carson 2017). Argumentation ability to be one of the main objectives of learning science (Probosari, Ramli, Harlita, Indrowati, \& Sajidan 2016). Relevant to the statement that scientific arguments are a major component of science education (Cetin 2014). Development and improvement of scientific knowledge are also done via tail scientific argumentation activities. The arguments will encourage students to engage in a variety of scientific practice and improve their knowledge of science concepts (Grooms, Enderle, \& Sampson 2015). The scientific explanation of the natural phenomena, concepts, theories, and principles in his special science subjects of physics must be understood in their entirety by learners. Therefore, the ability of argumentation becomes an essential foundation to gauge student understanding. The ability of scientific argumentation could observe construction understanding students' concept.

Learners who study science have to know the scientific explanation of natural phenomena and use it to solve problems. Until they can understand, other findings were obtained. Learners who understand science as a whole should be able to understand the language of science and actively participate in scientific activities such as observation and argument (Probosari 2016). The scientific argument is an important skill for students. Therefore, students should be given the opportunity to engage the arguments in class (Stanford, Moon, Towns, \& Cole 2016). The argument also becomes necessary to develop an understanding of scientific concepts learners (Heng, Surif, \& Seng 2015).

Research on the ability of learners' scientific arguments has been made. The results showed that the ability of the scientific arguments learners is at a low level (Probosari 2016). In general, the level of mastery of argumentation ability of learners between the group as well as individuals is not satisfactory. The results of this study indicate that the teaching and learning of science in schools should stress the argumentative group activities to enhance the scientific argument, reasoning ability and scientific knowledge learners (Heng, Surif, \& Seng 2014). Selection of appropriate methods in the learning process also affects the ability of argumentation learners. Learning methods of inquiry (inquiry) can be a suitable learning method. It is supported by research that shows that students who are taught to use inquiry-based model have a higher argumentation skill of the students taught using conventional learning models (Thoron \& Myers 2012). Results of other studies indicate that the technology has a special role when used with inquiry-based learning (invention) (Roblyer \& Doering 2010). Moel design integrated learning with technology become learners' needs in the 21 st Century Transitions millennia learning from generation $\mathrm{X}$ towards $\mathrm{Y}$ generation learners depends on the technology needs. Driven highly relevant learning technology used for student in Y-generation. The use of technology is expected to encourage the ICT literacy of learners in the 21 st Century So that demands 21st-century skills can be met. In general, Information Communication and Technology (ICT) can be analogized as a large umbrella terminology that covers all the technical equipment to process and communicates information (Arifin \& Setiyawan 2012).

How does the use of ICT and habits of students in managing ICT can be seen based on the study habits of students using ICT in schools? The role of teachers as professional educators is needed. Knowledge of technology (technology knowledge) and pedagogical knowledge (pedagogic knowledge) educators should be in line with the needs of students. Learning in the classroom should be directed integrated with technology. It is by the requirements and real situation on the ground. Students millennium more dependent on information technology and reduced tolerance of conventional teaching style (Qiang 2018).

Studying environmental effects when using digital technology provides a dynamic learning environment for teachers and students, as well as encourage the development of active students to use technology through innovative learning (Coll 2018; Blau \& Shamir-Inbal 2018). The problem is that 
the involvement of students in the use of technology in the learning process is still low (Howard, Ma \& Yang 2016). It could be an excellent opportunity for teachers and students. Teachers develop the role as an innovator in innovative learning by using ICT. Then the students can feel the digital learning environment in the classroom so that the increasing ability of scientific argumentation. Based on the above, the selection of appropriate learning models and the use of technology in learning can be a solution to improve the student's argument. Learning model that can be used is guided inquiry. Optimization technology uses guided inquiry learning model in line with the process of learning, especially learning physics. So the purpose of the application (pedagogic Technological Knowledge) teachers in the classroom TPK is expected to develop the communication skills of students in scientific argumentation. Role (pedagogic Technological Knowledge) TPK teachers in developing students' ability arguments shown in FIGURE 1.

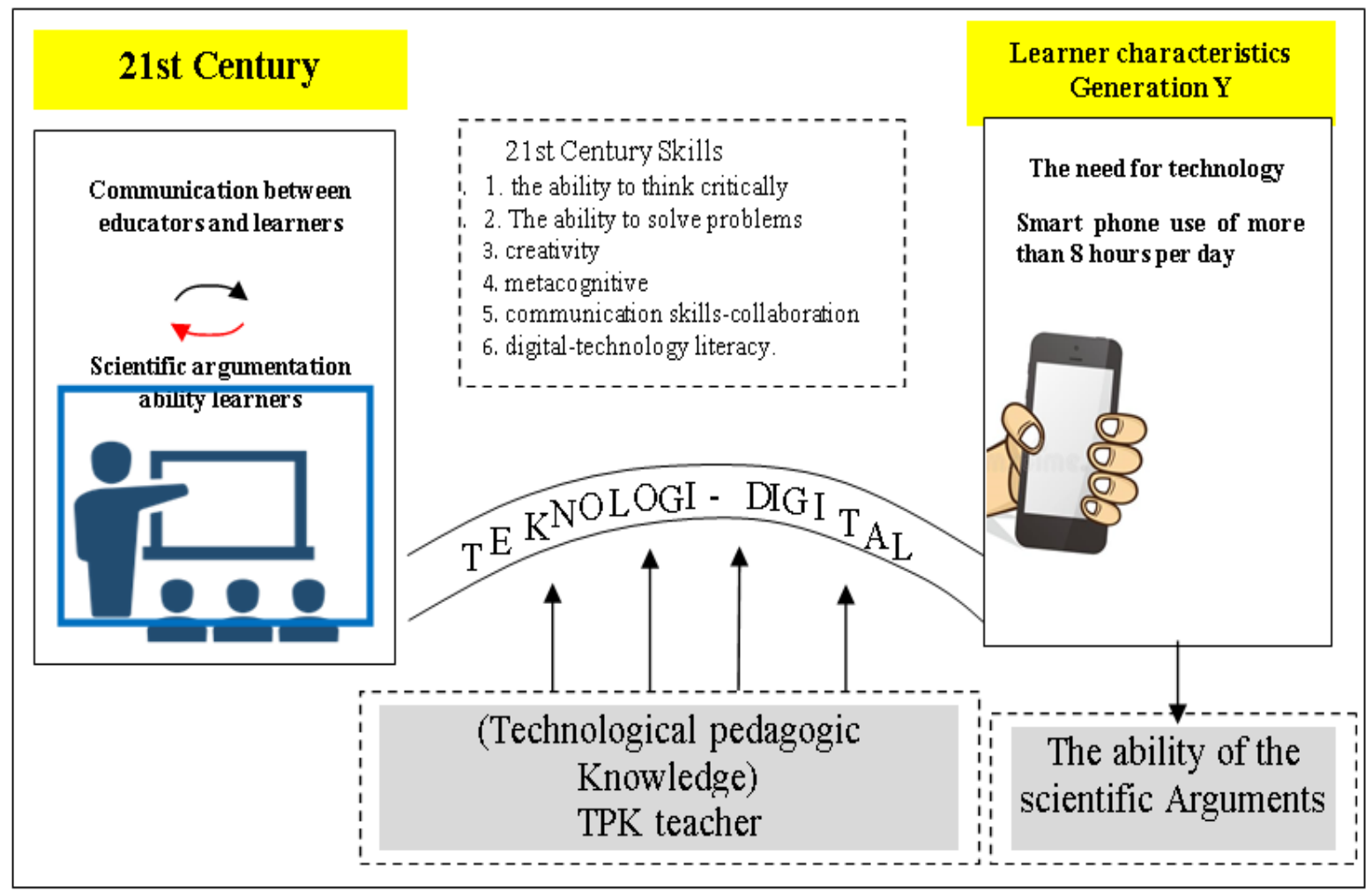

FIGURE 1. Relationships (pedagogic Technological Knowledge) TPK teacher, technology, and scientific argumentation ability learners.

Technology plays a role as a bridge of communication between teachers and students. Moreover, TPK teachers act as a support/foundation application of technology in classroom teaching activities. The goal is to encourage students' ability to scientific argumentation. The pedagogic ability of teachers chooses teaching model should be following the use of the technology used. The results showed that the technology has a special role when used with inquiry-based learning (invention) (Roblyer \& Doering 2010) so that the guided inquiry learning model has the potential to develop students' ability to scientific argumentation.

\section{RESEARCH METHODOLOGY}

Research conducted using a qualitative approach. The subjects were 28 students of class $\mathrm{X}$ at SMAN 1 Yogyakarta Prambanan. Pedagogical knowledge of teachers in using technology is realized through the use of 3D PageFlip student worksheets Impuls and Momentum material in the learning process. The learning method used is a guided inquiry. Data collected by giving a written test. The written test is presented in 3D PageFlip student worksheets. Analysis of the ability of students based on Toulmin Argumentation argumentation Pattern (TAP). TAP consists of claims, data, warrant, 
backing, qualifiers, and rebuttal (Toulmin 2003; Dawson \& Venville 2010). This study is part of the development of 3D PageFlip student worksheet to support the pedagogical knowledge and knowledge of technology (technological pedagogical knowledge) TPK teachers. The goal is to identify students' abilities through tests written arguments presented in the worksheet 3D PageFlip learners.

TABLE 1. Toulmin Argumentation Pattern (TAP 2003)

\begin{tabular}{|c|c|c|}
\hline level & Category & Activity \\
\hline level 1 & Claim & $\begin{array}{l}\text { Declaring an establishment (standpoint) in the form of claims. } \\
\text { Opinions on the value of the existing situation, and the } \\
\text { affirmation of the viewpoint. Claims submitted must be } \\
\text { supported by the data. }\end{array}$ \\
\hline level 2 & Data & $\begin{array}{l}\text { Data is a phenomenon that is used as evidence to support the } \\
\text { claim. }\end{array}$ \\
\hline level 3 & Warrant & $\begin{array}{l}\text { Justification is the rules and principles that explain the } \\
\text { relationship between the data and claims }\end{array}$ \\
\hline level 4 & Backing & $\begin{array}{l}\text { Support is the basic assumptions underlying specific } \\
\text { justification. }\end{array}$ \\
\hline level 5 & Qualifiers & $\begin{array}{l}\text { Statements made by learners based on what information is } \\
\text { accurate or correct theoretical physics. }\end{array}$ \\
\hline level 6 & Rebuttal & Refutation (rebuttal) is a rejection of the different arguments \\
\hline
\end{tabular}

\section{Pedagogical knowledge of teachers in using technology}

In this study, the ability of the student's argument depends on the pedagogical knowledge of teachers in using technology — the ability of the student arguments raised through guided inquiry learning (Guided Inquiry) using worksheets learners 3D PageFlip material impulse and momentum. Worksheet learners presented interactively using a variety of representations (verbal, visual, and video). Worksheet learners 3D PageFlip used in the study is shown in FIGURE 2. 


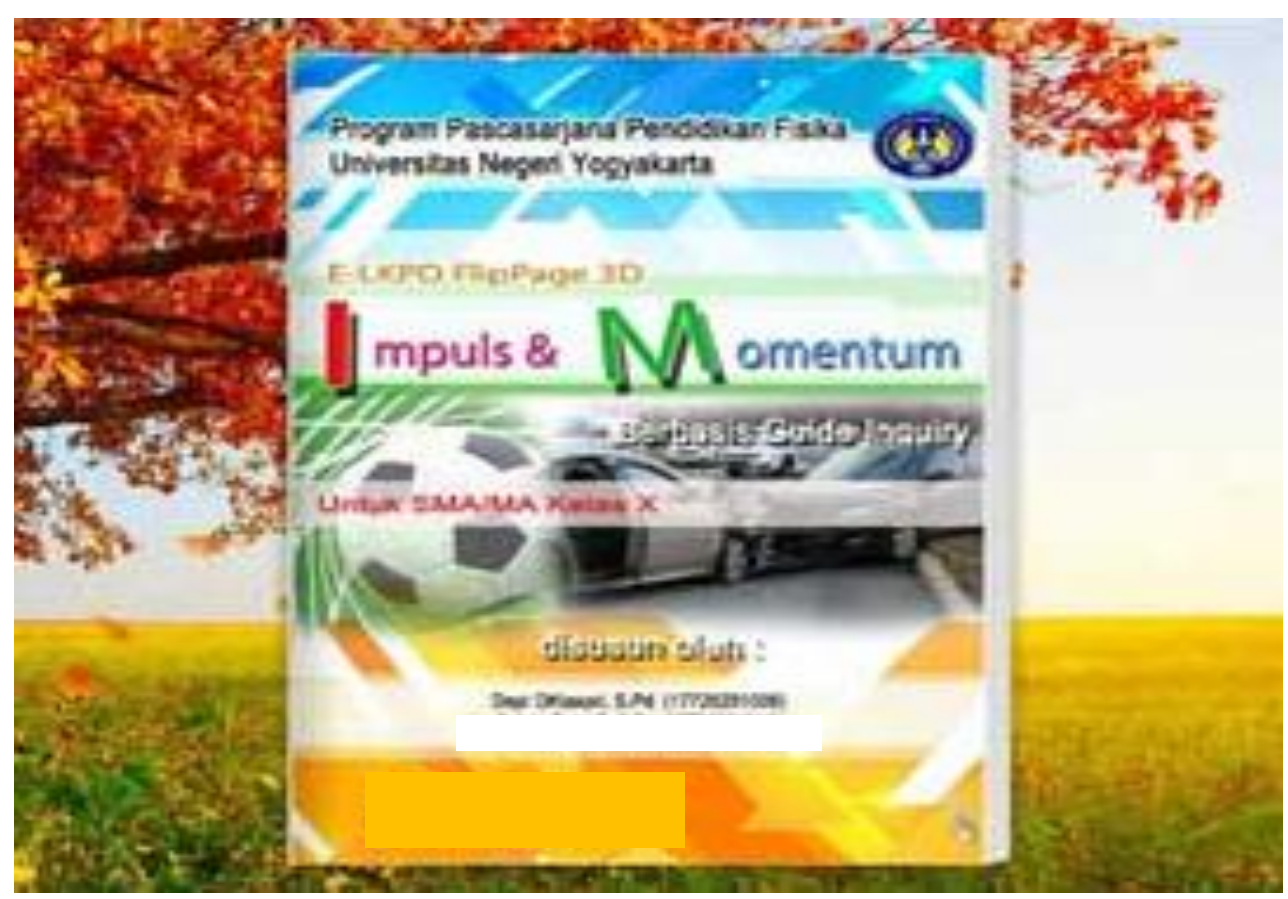

FIGURE 2. Worksheet learners PageFlip Material 3D Impuls and Momentum

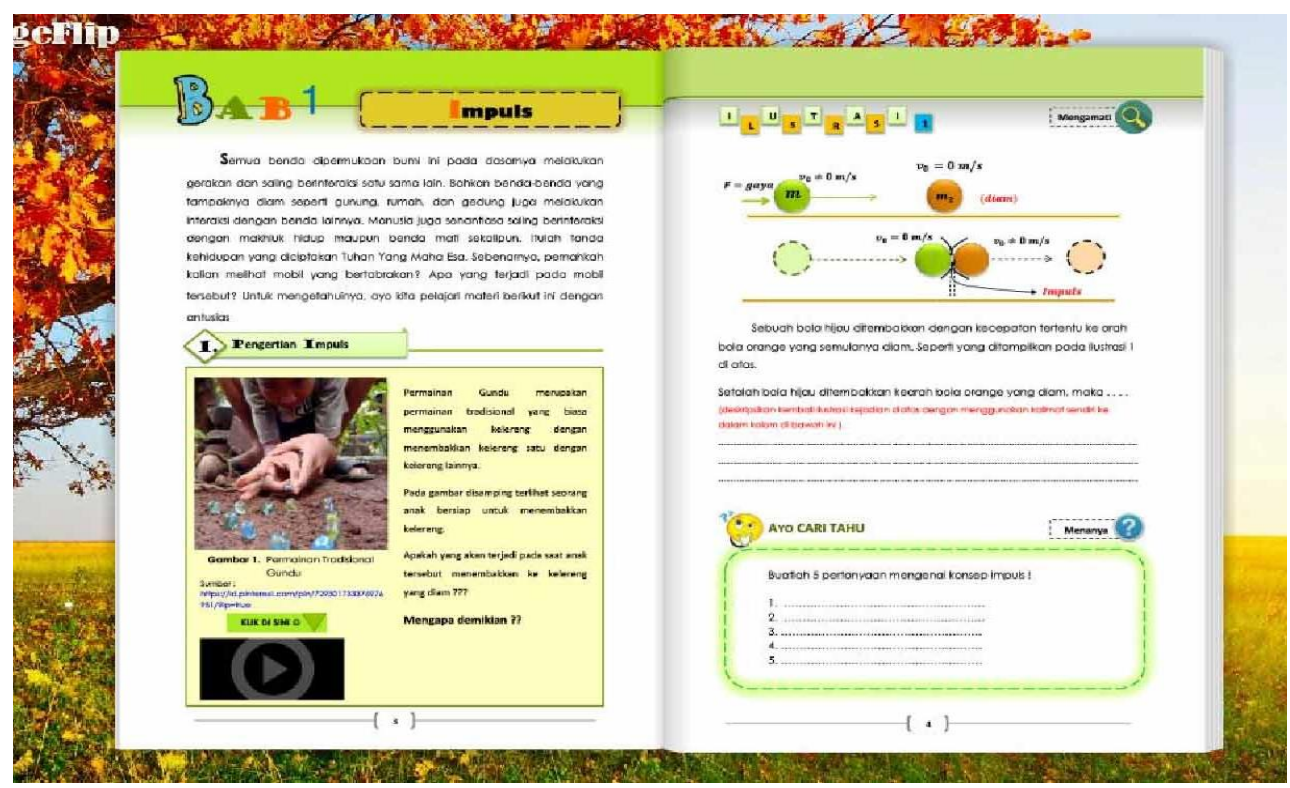

FIGURE 3. Display Worksheet 3D PageFlip learners Material Impuls and Momentum 


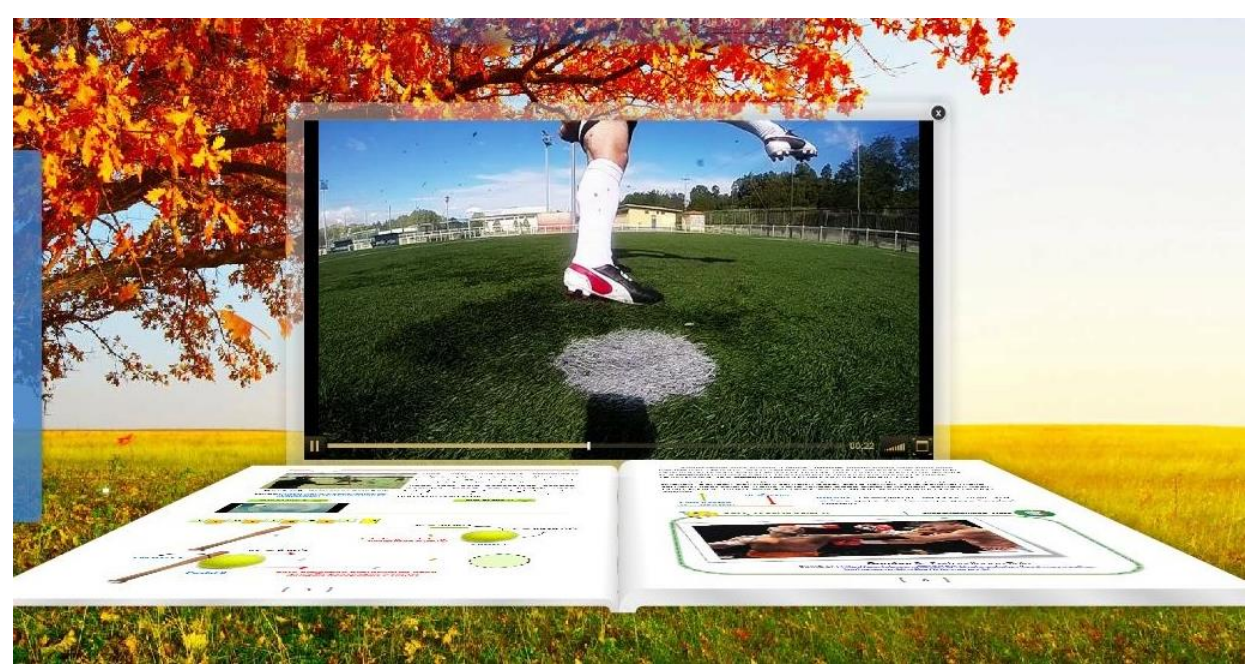

FIGURE 4. Display Worksheet 3D PageFlip learners Material Impuls and Momentum

Plan aided teaching is done with worksheets learners 3D PageFlip material Impuls and Momentum with guided inquiry learning model. The ability of the student's argument based on the level of ability was observed following arguments (Basel, Harms, \& Prechtl 2013).

TABLE 2. Categories complexity argument ability students

\begin{tabular}{ccc}
\hline & Argument Complexity \\
\hline Very High & Justified Claim & Rebuttal \\
High & Justified Claim & Qualifier or backing \\
Average & Claim & multiple grounds \\
low & Claim & single ground \\
Very Low & Claim & - \\
\hline
\end{tabular}

\section{RESULTS AND DISCUSSION}

This study aims to identify students' abilities arguments related to the understanding of the concept of impulse and momentum. Knowledge pedagogic and technology (technological pedagogical knowledge) TPK teacher role is to identify students' abilities argument — identification of argumentation ability of students starting with shows explanation of the concept of impulse and momentum in the form of multiple representations. Furthermore, Worksheet learners who have developed poured into technology 3D PageFlip served with guided inquiry-based learning model. The results of the students' answers on a worksheet the students analyzed refer to the pattern of argument Toulmin (TAP) (Toulmin 2003). Argumentation ability of students scoring rubric refers to TABLE 3. 
TABLE 3. Argumentation ability of student assessment rubric

\begin{tabular}{clcc}
\hline No & \multicolumn{1}{c}{ Indicator } & Average & Interp.Data \\
\hline 1. & $\begin{array}{l}\text { Writing opinions/arguments with clear and } \\
\text { understandable (Claim) }\end{array}$ & 3.0 & High \\
2. $\quad \begin{array}{l}\text { Using multiple representations in presenting their } \\
\text { opinions/arguments }\end{array}$ & 3.3 & High \\
3. $\quad \begin{array}{l}\text { Provide data to strengthen the opinion/argument } \\
\text { (Data) }\end{array}$ & 2.4 & Enough \\
4. Justifying a relationship between an argument with & 2.4 & Enough \\
the data that has been written. (Warrant) & $\begin{array}{l}\text { Jot supporting reasons related to the answers given } \\
\text { (Backing) }\end{array}$ & 2.3 & $\begin{array}{l}\text { Enough } \\
\text { Enough }\end{array}$ \\
\hline
\end{tabular}

Categories complexity argumentation ability of students refer to TABLE 2 (Basel, Harms, \& Prechtl 2013). Based on the results shown in TABLE 3, the complexity of the argumentation ability of students makes a claim higher when compared with the ability to create a search warrant and backing in general ability of argumentation new students to stage backing. The student claims process is shown in FIGURE 5.

Teacher: Why boxer is wearing boxing gloves during a match?

Student A: "to reduce the impulse force so little pain."

Student B: "to enlarge the time, and a little more style," "reduce impulse," "reduce that pain."

Students C: "to enlarge the time, and minimize style."

Students D: "to reduce pain during punching, and to protect the boxer's face."

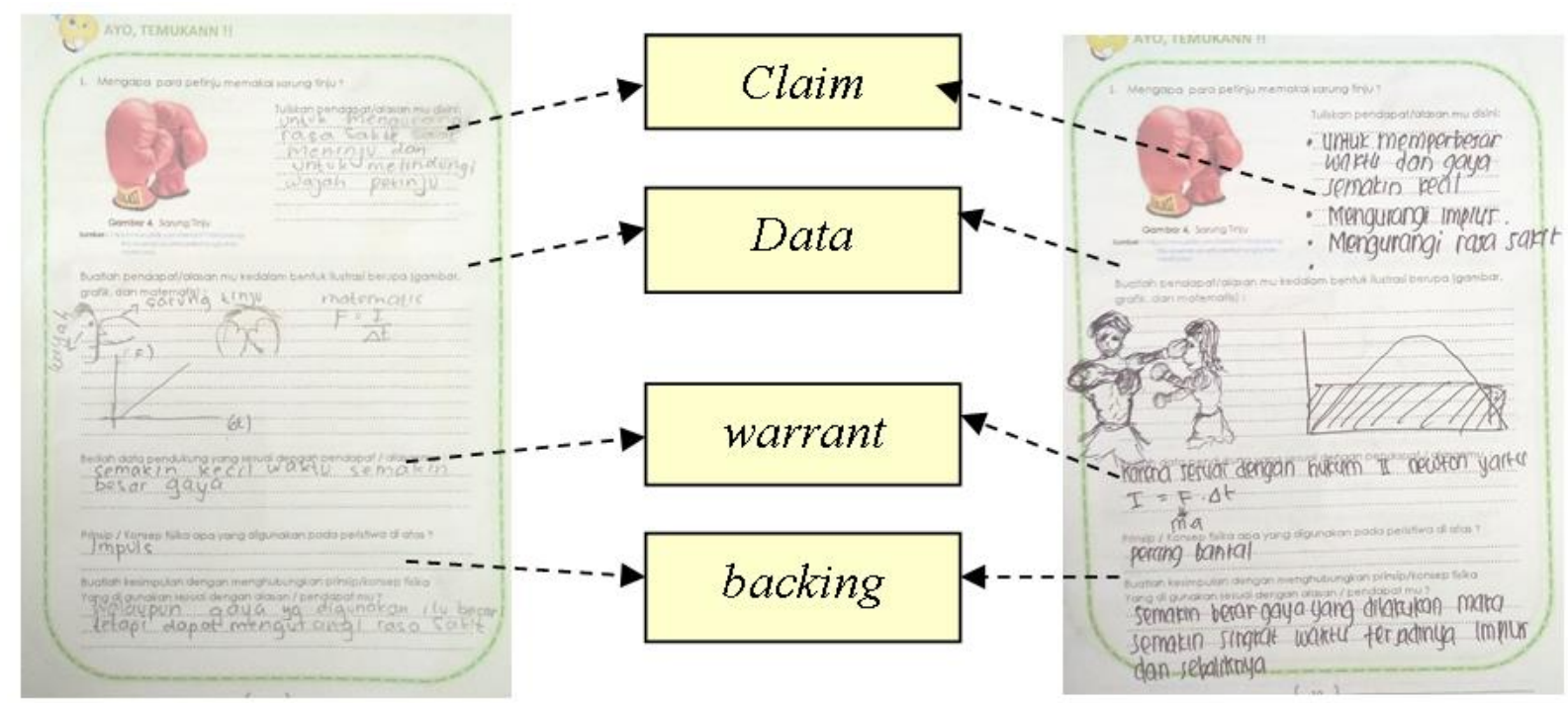

a) b)

FIGURE 5. The results of the students' answers A and student B 


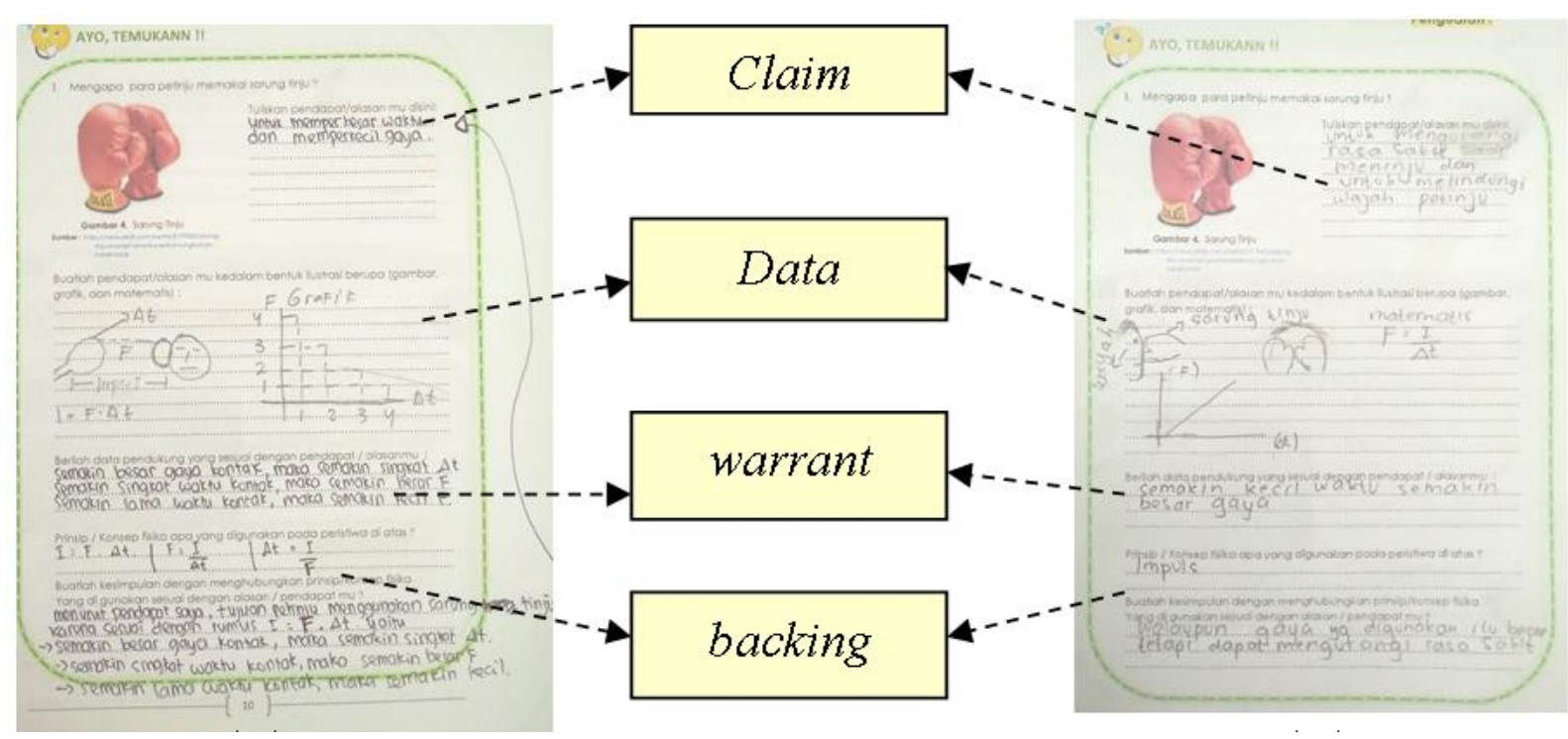

c)

d)

FIGURE 6. The results of the students' answers $C$ and D student

Based on FIGURE 5 and FIGURE 6, the ability of the students gave different claim from each other. Giving claim is the first part of the process of argumentation. Claim the right to explain the concept of impulse is to increase the contact time and minimize the contact force. In general, claim made by students are on a high level. However, the level of complexity has not shown the ability of argumentation - next, the provision of appropriate data to support the claim assisted by the use of multiple representations. Learning is more effective when the concepts learned are presented in various forms of representation (Ismet 2013). Presentation of data using different forms of representation should help students to support a claim that is written. However, the function of data to support the claim has not been evident in the results of the students' answers between the claim and the data provided as a stand-alone. Students are unable to connect to the claim that was written with the data they serve. Based on TABLE 3, at this stage of the presentation of the data that the students are at sufficient levels while the level of complexity of the ability of argumentation also categorized as very low.

Furthermore, warrants a statement of justification linking between arguments with data. This becomes the most important part. The level of complexity of the student's argument hinges on the ability of students to organize any claim, data, warrants, and backing are made. Based on FIGURE 5 and FIGURE 6, Warrant (justification) written by the student B looks more complex when compared with the results of the students' answers A, C students, and students D. TABLE 3 shows that the ability of students to justify a search warrant in the category enough. At this stage the complexity of argumentation ability incoming students in the low category. Students' ability to make backing write supporting reasons related to the answers given are at sufficient levels.

Argumentation ability of students in constructing the relationship between the claims, data, warrants, and backing must often be trained. Toulmin's argument pattern (Toulmin 2003; Dawson \& Venville 2010). In this study identifies four components, include; claim, data, warrants, and backing. The results showed that, the construction of argumentation ability students must often be trained. It is shown that, complexity argumentation ability of students that are in the low category. Therefore, students should always be facilitated to develop the ability of the argument.

\section{CONCLUSIONS}

Based on the analysis of data, the ability of students to make a claim argumentation achieved a score of 3 , with a high category. The ability of students to make the data argument reached a score of 2.4 with sufficient category. Furthermore, the ability of the arguments made warrant achieved a score of 2.4 , with the category enough. It is directly proportional to the ability of the student's argument 
makes backing achieved a score of 2.3 , with the category enough. In general, the complexity of argumentation ability of students is at a low level (claims with a single ground).

\section{REFERENCES}

A Sadiman, AS, Rahardjo, R, Haryono, AR 2010, Media Pendidikan: Pengertian, Pengembangan, dan Pemanfaatannya, Pustekkom Dikbud dan PT. Grafindo Persada, Jakarta.

Arifin, Z, Setiyawan, A 2012, 'Pengembangan Pembelajaran Aktif dengan ICT', Skripta Media Creative, vol. 7, no. 8, p. 9.

Basel, N, Harms, U, \& Prechtl, H 2013, 'Analysis of Students' Arguments on Evolutionary Theory,' Journal of Biological Education, vol. 47, no. (4), pp. 192-199, doi: http://dx.doi.org/10.1080/00219266.2013.799078

Bell, M, Carr, P 2014, 'Building Communication Skills for Science Students in Video-Conference Tutorials,' International Journal of Innovation in Science and Mathematics Education, vol. 22, no. 4 , pp. 65-78.

Blau, I, \& Shamir-Inbal, T 2018, 'Digital Technologies for Promoting "Student Voice" and CoCreating Learning Experience in an Academic Course', Instructional Science, vol. 46, no. 2, pp. 315-336, doi: http://dx.doi.org/10.1007/s11251-017-9436-y

Cetin, PS 2014, 'Explicit Argumentation Instruction to Facilitate Conceptual Understanding and Argumentation Skills,' Research in Science \& Technological Education, vol. 32, no. 1, pp. 1-20, doi: http://dx.doi.org/10.1080/02635143.2013.850071

Coll, SD, Coll, RK 2018, 'Using Blended Learning and Out-Of-School Visits: Pedagogies for Effective Science Teaching in The Twenty-First Century,' Research in Science \& Technological Education, vol. 36, no. 2, pp. 185-204, doi: http://dx.doi.org/10.1080/02635143.2017.1393658

Crowell, A, \& Kuhn, D 2014, 'Developing Dialogic Argumentation Skills: A 3-Year Intervention Study', Journal of Cognition and Development, vol. 15, no. 2, pp. 363-381, doi: http://dx.doi.org/10.1080/15248372.2012.725187

Dawson, VM, Venville, G 2010, 'Teaching Strategies For Developing Students' Argumentation Skills About Socioscientific Issues In High School Genetics,' Research in Science Education, vol. 40, no. 2, pp. 133-148, doi: http://dx.doi.org/10.1007/s11165-008-9104-y

Dawson, V, Carson, K 2017, 'Using climate change scenarios to assess high school students' argumentation skills,' Research in Science \& Technological Education, vol. 35, no. 1, pp. 1-16, doi: http://dx.doi.org/10.1080/02635143.2016.1174932

Didi, S, \& Deni, D 2012, Komunikasi Pembelajaran, PT Remaja Rosdakarya, Bandung.

Greenstein, LM 2012, Assessing 21st Century Skills: A Guide to Evaluating Mastery and Authentic Learning, Corwin Press.

Grooms, J, Enderle, P, Sampson, V 2015, 'Coordinating Scientific Argumentation and the Next Generation Science Standards through Argument-Driven Inquiry', Science Educator, vol. 24, no. 1, pp. 45-50, doi: http://nsela.org/publications/science-educator-journal

Heng, LL, Surif, JB, \& Seng, CH 2014, 'Individual versus group argumentation: Student's performance in a Malaysian context,' International Education Studies, vol. 7, no. 7, pp.109-124.

Heng, LL, Surif, JB, \& Seng, CH 2015, 'Malaysian Students' Scientific Argumentation: Do groups Perform Better Than Individuals?', International Journal of Science Education, vol. 37, no. 3, pp. 505-528, doi: http://dx.doi.org/10.1080/09500693.2014.995147

Howard, S., Ma, J, \& Yang, J 2016, 'Student Rules: Exploring Patterns of Students' ComputerEfficacy and Engagement with Digital Technologies in Learning,' Computers \& Education, vol. 101, pp. 29-42. 
Ismet 2013, 'Pengembangan Program Perkuliahan Mekanika Berbasis Multiple Representations Untuk Meningkatkan Kecerdasan Spasial (Spatial Intelligence) Mahasiswa Calon Guru', Jurnal Pendidikan Fisika Indonesia, ISSN: 1693-1246, vol. 9, pp. 132-143.

Mao, L, Liu, OL, Roohr, K, Belur, V, Mulholland, M, Lee, HS, \& Pallant, A 2018, 'Validation of Automated Scoring for a Formative Assessment that Employs Scientific Argumentation', Educational Assessment, vol. 23, no. 2, pp. 121-138, doi: http://dx.doi.org/10.1080/10627197.2018.1427570

Mukarom, Z, Rusdiana, A, Rusdiana, A 2016, Komunikasi dan Teknologi Informasi Pendidikan, Pustaka Setia, Bandung.

Probosari, RM, Ramli, M, Harlita, H, Indrowati, M, Sajidan, S 2016, 'Profil Keterampilan Argumentasi Ilmiah Mahasiswa Pendidikan Biologi FKIP UNS pada Mata Kuliah Anatomi Tumbuhan', Bioedukasi: Jurnal Pendidikan Biologi, vol. 9, no. 1, pp. 29-33.

Qiang, J 2018, 'Effects of Digital Flipped Classroom Teaching Method Integrated Cooperative Learning Model on Learning Motivation and Outcome,' EURASIA Journal of Mathematics, Science and Technology Education, vol. 14, no. 6, pp. 2213-2220.

Roblyer, MD, Doering, AH 2010, Integrating Educational Technology Into Teaching (4th), Merrill Prentice Hall, Columbus.

Scheuer, O, Loll, F, Pinkwart, N, McLaren, BM 2010, 'Computer-Supported Argumentation: A Review of The State of The Art,' International Journal of Computer-Supported Collaborative Learning, vol. 5, no. 1, pp. 43-102, doi: http://dx.doi.org/10.1007/s11412-009-9080-x

Stanford, C, Moon, A, Towns, M, \& Cole, R 2016, 'Analysis of instructor facilitation strategies and their influences on student argumentation: A case study of a process-oriented guided inquiry learning physical chemistry classroom,' Journal of Chemical Education, vol. 93, no. 9, pp. 15011513. Doi: http://dx.doi.org/10.1021/acs.jchemed.5b00993

Thoron, AC, Myers, BE 2012, 'Effects of Inquiry-Based Agriscience Instruction and Subject MatterBased Instruction on Student Argumentation Skills,' Journal of Agricultural Education, vol. 53, no. 2, pp. 58-69, doi: http://dx.doi.org/10.5032/jae.2012.02058

Toulmin, SE 2003, The uses of argument, Cambridge University Press. 